\title{
Three Cases of Liver Injury Caused by Sennomotokounou, a Chinese Dietary Supplement for Weight Loss
}

\author{
Kazuhito Kawata, Yasunori TAKeHIRA, Yoshimasa KobaYASHI*, Mutsuo Kitagawa, \\ Masami Yamada, Kazunori HanaJima, Gou Murohisa, Motoko KaWamura, \\ Yasushi IwAOKA, Tomohiko WADA, Satoru MoRITA, Moriya IwAIZUMI and Satuki MAKINO
}

\begin{abstract}
Dietary supplements have become very popular worldwide because they are believed to be safe with few side effects. Here, we report three cases of liver injury caused by Sennomotokounou, a Chinese dietary supplement for weight reduction. All patients developed acute hepatotoxicity and recovered spontaneously after withdrawal of dietary product. This product contains fenfluramine, $n$ nitroso-fenfluramine, and dried thyroid tissue powder. In Japan, the regulatory agency for drug and food safety received 120 reports of hepatotoxicity associated with Sennomotokounou between 2000 and 2002. Physicians should inquire about the use of dietary supplements whenever patients present with unexplained acute liver dysfunction.
\end{abstract}

(Internal Medicine 42: 1188-1192, 2003)

Key words: hepatotoxicity, hyperthyroidism, dietary supplement, n-nitroso-fenfluramine

\section{Introduction}

Dietary supplements are widely used throughout the world because they are assumed to be harmless compared with conventional drugs. However, hepatotoxicity due to dietary supplements has been increasingly recognized (1). We report here three cases of liver injury caused by Sennomotokounou, a Chinese dietary supplement. This popularly used supplement for weight reduction in Japan was recently removed from the market because of its hepatotoxic adverse reactions.
Case Report

\section{Case 1}

A 63-year-old Japanese woman presented with a 2-week history of jaundice. She had taken Sennomotokounou for 6 weeks. On examination, she was icteric without fever or hepatosplenomegaly. Laboratory data showed total bilirubin of $13.4 \mathrm{mg} / \mathrm{dl}$ (normal $0.4-0.9$ ), direct bilirubin of 11.68 $\mathrm{mg} / \mathrm{dl}(0-0.4)$, aspartate aminotransferase (AST) of 1,675 IU/l (8-40), alanine aminotransferase (ALT) of $1,877 \mathrm{IU} / l$ (5-35), and alkaline phosphatase (ALP) of 559 IU/l (90224). Prothrombin time and serum albumin level were normal. Viral serological tests (hepatitis A, B, and C viruses) and antinuclear antibodies were all negative. A lymphocyte transformation test (LTT) for Sennomotokounou was not performed. Abdominal ultrasonography and computed tomography did not show any hepatic or biliary abnormalities. As shown in Fig. 1A, she recovered spontaneously after Sennomotokounou was withdrawn. One month later, serum total bilirubin level decreased to $4.9 \mathrm{mg} / \mathrm{dl}$; serum AST, ALT, and ALP were $21 \mathrm{IU} / l, 19 \mathrm{IU} / l, 336 \mathrm{IU} / l$, respectively. A liver biopsy performed two months after withdrawal of dietary product showed mild hepatocellular steatosis and drop-out in the centrilobular areas (Fig. 2). The histological findings were consistent with those of drug-induced liver injury.

\section{Case 2}

A 24-year-old Japanese woman presented with a oneweek history of jaundice and appetite loss. She had taken Sennomotokounou for one month. On examination, she was icteric, afebrile, and did not have hepatosplenomegaly. Laboratory data were as follows: total bilirubin $6.4 \mathrm{mg} / \mathrm{dl}$, direct bilirubin $5.0 \mathrm{mg} / \mathrm{dl}$, AST 1,085 IU/l, ALT 2,016 IU/l, and ALP $397 \mathrm{IU} / l$. Viral serological tests (hepatitis A, B, and

From the Department of Gastroenterology, Hamamatsu Medical Center, Hamamatsu and *the Second Department of Internal Medicine, Hamamatsu University School of Medicine, Hamamatsu

Received for publication January 9, 2003; Accepted for publication September 17, 2003

Reprint requests should be addressed to Dr. Kazuhito Kawata, the Department of Gastroenterology, Hamamatsu Medical Center, 328 Tomitsuka-cho, Hamamatsu 432-8580 


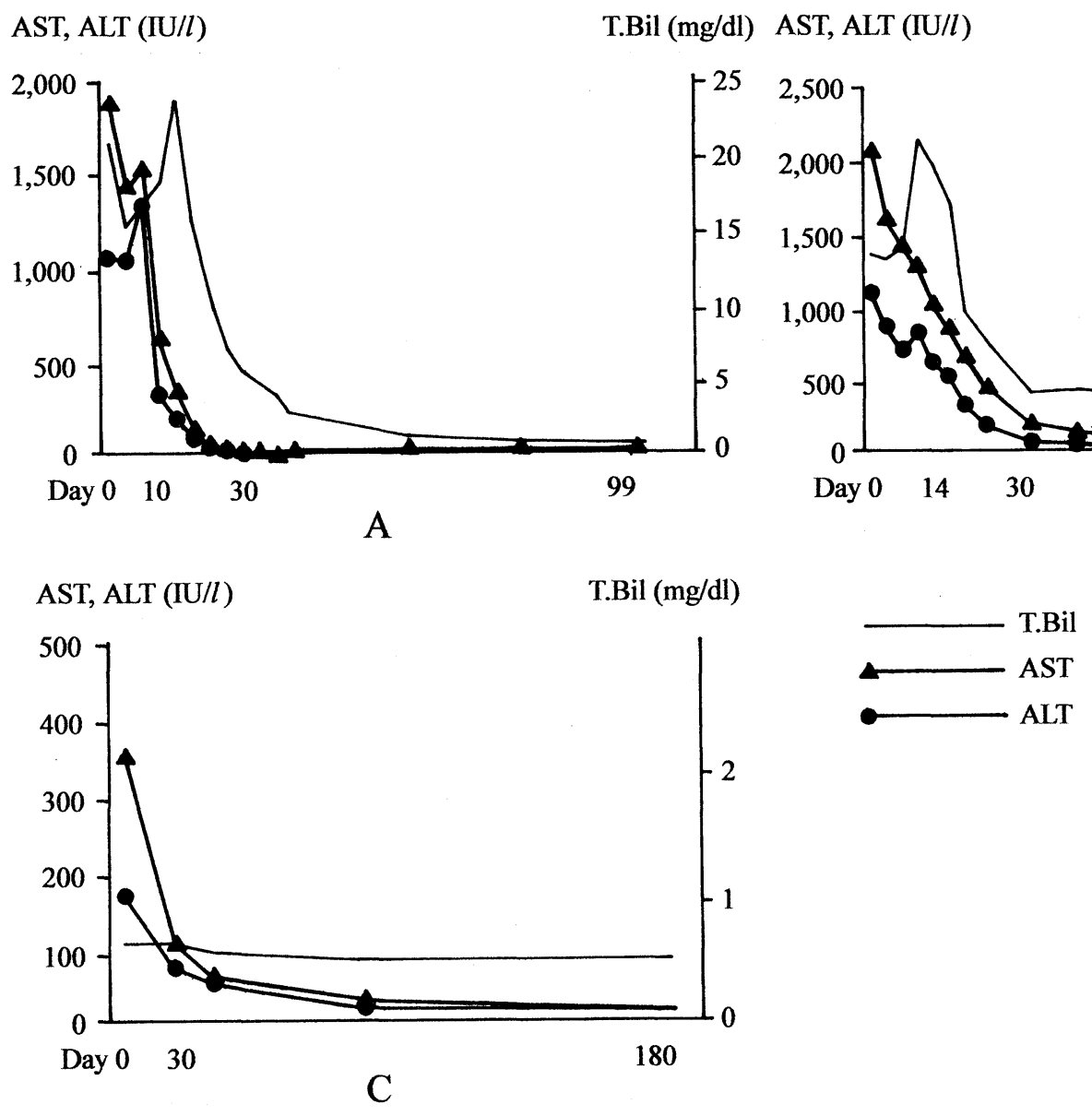

Figure 1. Clinical courses of hepatic injury caused by Sennomotokounou. (A) case 1, (B) case 2, (C) case3.

C viruses) were negative. LTT for Sennomotokounou was negative. Abdominal ultrasonography and computed tomography showed only mild hepatomegaly. Three days after withdrawal of the dietary product, serum thyroid stimulating hormone (TSH) level was below the lower detection limit (normal, 0.5-4.8 $\mu \mathrm{U} / \mathrm{ml}$ ) with serum free triiodothyronine $\left(\mathrm{fT}_{3}\right)$ of $2.81 \mathrm{pg} / \mathrm{ml}(2.5-6.0 \mathrm{pg} / \mathrm{ml})$, and free thyroxine $\left(\mathrm{fT}_{4}\right)$ of $1.45 \mathrm{ng} / \mathrm{dl}(0.8-1.9 \mathrm{ng} / \mathrm{dl})$. Serum thyroglobulin level was $<5.0 \mathrm{ng} / \mathrm{ml}(<30 \mathrm{ng} / \mathrm{ml})$; anti-TSH receptor and thyroid stimulating antibodies were negative. The clinical course is shown in Fig. 1B. One month after withdrawal of the dietary product, jaundice disappeared, and serum AST and ALT levels decreased to $52 \mathrm{IU} / l$ and $173 \mathrm{IU} /$ $l$, respectively. Thyroid function tests returned to normal.

\section{Case 3}

A 53-year-old Japanese woman visited our clinic because she noted dark urine one month prior to visit. She had taken Sennomotokounou for 6 weeks. On examination, she was not icteric and did not have hepatosplenomegaly. Laboratory data showed total bilirubin of $0.47 \mathrm{mg} / \mathrm{dl}$, direct bilirubin of $0.16 \mathrm{mg} / \mathrm{dl}$, AST of $177 \mathrm{IU} / \mathrm{l}$, ALT of $352 \mathrm{IU} / \mathrm{l}$, and ALP of
772 IU/l. Prothrombin time was normal. Viral serological tests (hepatitis B and C viruses) were negative. LTT for Sennomotokounou was negative. Serum TSH was 0.39 $\mu \mathrm{U} / \mathrm{ml}$ with serum $\mathrm{fT}_{3}$ of $3.08 \mathrm{pg} / \mathrm{ml}$, and $\mathrm{fT}_{4}$ of $0.61 \mathrm{ng} / \mathrm{dl}$. The clinical course is shown in Fig. 1C. Two months later, liver function tests returned to normal.

The three patients had no history of hepatitis, blood transfusion, homosexual contact or excess alcohol consumption. Considering the clinical course, particularly recovery from liver injury after cessation of the dietary product, Sennomotokounou, was the likely cause of their hepatic injury.

\section{Discussion}

Dietary supplements are popular throughout the world, and the market is a multibillion-dollar industry. Competition has driven dietary supplement manufacturers to seek obscure ingredients and to use them in nontraditional manners without adequate evaluation of the safety and adverse effects. Unlike approved drugs, dietary supplements are not tightly controlled by the regulatory agencies for drug and food safety before marketing. The manufacturers of these products 

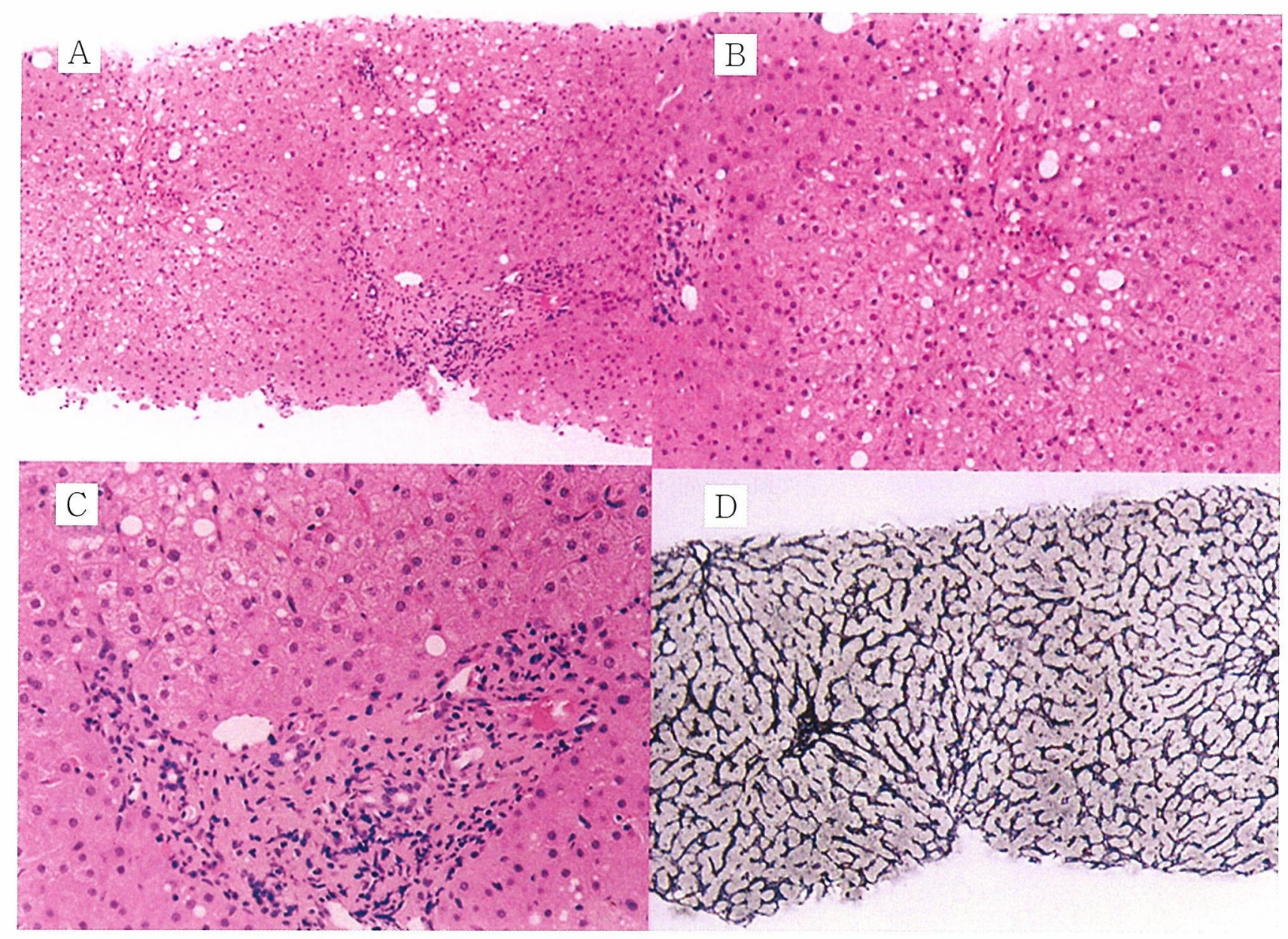

Figure 2. Liver biopsy specimen taken from case 1. (A) The histological features are compatible with those in the recovery stage of drug-induced liver injury. (B) Mild hepatocellular steatosis and drop-out with mild infiltration of inflammatory cells are seen in the centrilobular areas. (C) The portal tracts are enlarged with mild infiltration of mononuclear cells without peacemeal necrosis and fibrosis. There is no esinophil infiltration (HE stain, original magnification, $\mathrm{A} \times 40 ; \mathrm{B} \times 160 ; \mathrm{C} \times 160$ ), (D) The lobular architecture is preserved (reticulin stain; original magnification $\times 60$ ).

are not pressured to ensure that the product label information is truthful and not misleading. In addition, a common misconception is that dietary supplements are harmless compared with conventional drugs. Because of these conditions, the hepatotoxicity of dietary supplements has been increasingly recognized (1). We report three healthy people who developed hepatotoxicity while taking Sennomotokounou, a Chinese dietary supplement marketed for weight loss. The clinical summary is presented in Table 1 . All patients had taken the supplement for 4 to 6 weeks. Cases 1 and 2 presented with symptoms and liver dysfunction characteristic of acute hepatitis, while case 3 represented the recovery stage of acute hepatitis. There was no evidence of allergies, such as rashes or eosinophilia. The LTT, a test to identify drugs responsible for immunological side effects (2), was negative for Sennomotokouno in Case 2 and Case 3. All of the patients recovered spontaneously after discontinuing Sennomotokounou, and their liver test results normalized within 6 months. No other hepatotoxic agent or other cause for hepatotoxicity could be identified.

The diagnosis of drug-induced liver injury is usually based on circumstantial evidence. Recently, a clinical diagnostic scale has been developed for the diagnosis of druginduced liver injury and it has been considered to be suitable for use in routine clinical practice by Maria and Victorino (3). In the scoring system, five components are selected: the temporal relationship between drug intake and the clinical picture, exclusion of alternative causes, extrahepatic manifestations, rechallenge or accidental re-exposure, and previous reports in the medical literature. The relative importance of each component is weighed, and arbitrary scores are attributed. The probability of the diagnosis of drug-induced liver injury is expressed as a final score, and is graded as either definite drug hepatotoxicity (score $>17$ ), probable (1417), unlikely (6-9), or drug hepatotoxicity excluded $(<6)$. As for the present cases, according to this scoring system, all 
Dietary Supplement Hepatotoxicity

Table 1. Clinical Characteristics in Patients with Sennomotokounou-Associated Hepatotoxicity

\begin{tabular}{|c|c|c|c|c|c|c|c|c|}
\hline \multirow{2}{*}{$\begin{array}{l}\text { Patient } \\
\text { No. }\end{array}$} & \multirow{2}{*}{$\begin{array}{l}\text { Age } \\
\text { Sex }\end{array}$} & \multirow{2}{*}{$\begin{array}{l}\text { Duration of drug } \\
\text { intake (days) }\end{array}$} & \multicolumn{5}{|c|}{ Serum Level* } & \multirow{2}{*}{$\begin{array}{l}\text { Duration of Liver } \\
\text { dysfunction (days) }\end{array}$} \\
\hline & & & $\begin{array}{l}\text { T.Bil. } \\
\text { (mg/dl) }\end{array}$ & $\begin{array}{l}\text { ALT } \\
(\mathrm{IU} / l)\end{array}$ & $\begin{array}{l}\mathrm{AST} \\
(\mathrm{IU} / l)\end{array}$ & $\begin{array}{c}\text { ALP } \\
(\mathrm{IU} / l)\end{array}$ & $\begin{array}{l}\gamma \mathrm{GTP} \\
(\mathrm{IU} / \mathrm{l})\end{array}$ & \\
\hline 1 & $\begin{array}{c}63 \\
F\end{array}$ & 43 & 13.4 & 1,877 & 1,675 & 559 & 454 & 100 \\
\hline 2 & $\begin{array}{c}24 \\
F\end{array}$ & 30 & 6.4 & 2,016 & 1,085 & 397 & 127 & 180 \\
\hline 3 & $\begin{array}{l}52 \\
\mathrm{~F}\end{array}$ & 45 & 0.5 & 352 & 177 & 772 & 305 & 60 \\
\hline
\end{tabular}

T.Bil.: total bilirubin, ALT: alanineaminotransferase, AST: asparate aminotransferase, ALP: alkaline phosphatase, $\gamma \mathrm{GTP}$ : $\gamma$-glutamyl transpeptidase. *The normal reference ranges were as follows: T.Bil., 0.4-0.9 mg/dl; ALT, 5-35 IU/l; AST, 8-40 IU/l; ALP, 90-224 IU/l; GTP, 7-50 IU/l.

were diagnosed as having "probable" drug hepatotoxicity.

Sennomotokounou contains eleven types of herbal products, kudzuvine roots, coix seeds, hawthorn fruit, wolfberry fruit, chrysanthemum flowers, lotus leaves, tangle kelp, radish seeds, cassia seeds, and jiaogulan leaf and tea leaf extracts according to the product label information. No published reports have described hepatotoxicity associated with any of these herbal products. Recently, the Japan National Institute of Health Sciences (NIHS) found fenfluramine (about 0.01\%), n-nitroso-fenfluramine (about $3 \%$ ) and dried thyroid tissue powder in the dietary supplement \{ref. the Japan Ministry of Health, Labour and Welfare (MHLW) Web site; www.mhlw.go.jp/houdou/2003/02/h02121.htm (12 February 2003) (in Japanese)\}. N-nitrosofenfluramine is synthesized from fenfluramine (Fig. 3), and is unlicensed for drugs, food and food additives. There is no information on its pharmacological effects and toxicities in animals and humans. On the other hand, fenfluramine is an amphetamine derivative which blocks serotonin uptake, provoking transport-mediated serotonin release. It was popularly used as an anoretic agent in Western Europe and North America previously (4). The use of fenfluramine is prohibited because primary pulmonary hypertension, valvular heart disease and neurotoxicity are associated with its use (5-8). As for hepatotoxicity, there is only one report of fatal hepatitis after taking herbal medicine and dexfenfluramine, which is a dextro-isomer of fenfluramine (9). The manufacturer of Sennomotokounou probably used n-nitroso-fenfluramine as an anorexic agent instead of fenfluramine because the use of fenfluramine is illegal. Several nitroso-compounds are well known to induce hepatic injury in animals (10). Recently, the NIHS reported that n-nitrosofenfluramine induced hepatic injury in experimental animals (ref. the Japan MHLW Web site). Although a hepatotoxin was not clearly identified in Sennomotokounou, many mechanisms could be responsible for the observed hepatotoxicity. These include toxic effects related to interactions of the ingredients in the product, such as trigger and potentiation. Various factors may explain these interactions, including the induction of certain enzymes or

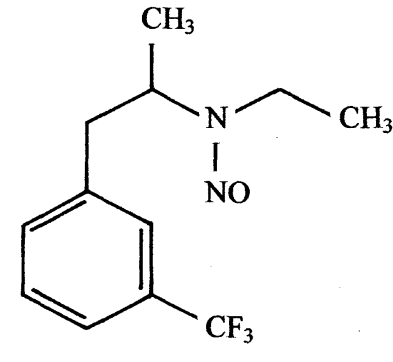

Fenfluramine

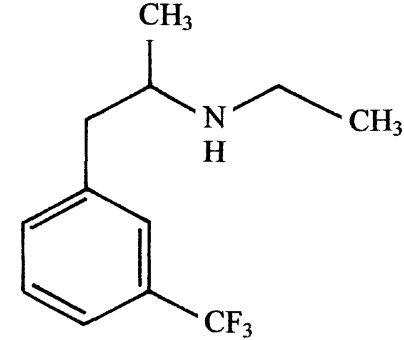

n-nitroso-fenfluramine
Figure 3. Structural formulas of fenfluramine and n-nitrosofenfluramine.

formation of secondary toxic metabolites due to alterations in pharmacokinetic and pharmacodynamic properties of certain ingredients. Alternatively, a pharmacogenetic predisposition may contribute to Sennomotokounou-induced hepatotoxicity.

Hyperthyroidism should be considered as another serious side effect of Sennomotokounou, which contains thyroid hormones, mainly $\mathrm{T}_{3}$. In the present cases, the serum TSH level was suppressed with normal serum free thyroid hormone levels. If thyroid function had been evaluated immediately after drug withdrawal, serum thyroid hormone levels would have been elevated. Hepatic dysfunction is often observed in patients with hyperthyroidism. Jaundice may be due to congestive heart failure as a complication of thyrotoxicosis and aggravation of an underlying defect in serum bilirubin metabolism, such as Gilbert's syndrome (11). Hepatobiliary enzymes may also increase mildly in patients with uncomplicated hyperthyroidism $(12,13)$. In our cases, the abnormal liver test results were not typical of the pattern of hepatic dysfunction observed in hyperthyroidism. Although there is no evidence of direct hepatotoxic effects due to thyroid hormones, it is known that they sensitize the liver to some hepatotoxicants (14-16). Hyperthyroidism may 


\section{KAWATA et al}

have triggered or exacerbated the hepatic injury in our cases.

In Japan, the regulatory agency for the drug and food safety received over 850 reports of adverse events or illness while taking Chinese dietary supplements, including Sennomotokounou, between 2000 and 2002; for Sennomotokounou, there were 120 reports of hepatotoxicity and 32 reports of thyroid dysfunction, including 9 reports with both \{ref. the Japan MHLW Web site\}. Dietary supplements are commonly used without information of the potential risk including hepatotoxicity. Patients often do not mention the use of a dietary supplement; this may result in a diagnostic delay as well as perpetuation or exacerbation of adverse reactions. Health professionals should be encouraged to inquire routinely about the use of dietary supplements. In addition, challenges for the future include the need for appropriate reporting and regulatory systems to monitor adverse effects of dietary supplements.

\section{Addendum}

Since this article was submitted for publication, two similar case reports $(17,18)$ and one review article regarding the hepatotoxicity due to Chinese dietary supplements for weight loss (19) have appeared in the Japanese language.

\section{References}

1) Stedman C. Herbal hepatotoxicity. Semin Liver Dis 22: 195-206, 2002.

2) Maria VA, Pinto L, Victorino RM. Lymphocyte reactivity to ex-vivo drug antigen in drug-induced hepatitis. J Hepatol 21: 151-158, 1994.

3) Maria VA, Victorino RM. Development and validation of a clinical scale for the diagnosis of drug-induced hepatitis. Hepatology 26: 664669, 1997.

4) Halpern A, Mancini MC. Treatment of obesity: an update on antiobesity medications. Obes Rev 4: 25-42, 2003

5) Von Muhlendahl KE, Krienke EG. Fenfluramine poisoning. Clin
Toxicol 14: 97-106, 1979.

6) McCann UD, Seiden LS, Rubin LJ, Ricaurte GA. Brain serotonin neurotoxicity and primary pulmonary hypertension from fenfluramine and dexfenfluramine. A systematic review of the evidence. JAMA 278: 666-672, 1997.

7) Fiedman MA, Woodcock J, Lumpkin MM, Shuren JE, Hass AE, Thompson LJ. The safety of newly approved medicines: do recent market removals meam there is a problem? JAMA 281: 1728-1734 1999 (see comments).

8) Sachdev M, Miller WC, Ryan T, Jollis JG. Effect of fenfluraminederivative diet pills on cardiac valves: a meta-analysis of observational studies. Am Heart J 144: 1065-1073, 2002.

9) Mostefa-Kara N, Pauwels A, Pines E, Bilour M, Levy VG. Fatal hepatitis after herbal tea. Lancet 340: 674, 1992 (letter).

10) Schoeffner DJ, Thorgeirsson UP. Susceptibility of nonhuman primates to carcinogens of human relevance. In Vivo 14: 149-156, 2000.

11) Sherlock S. Nutritional and metabolic liver diseases: liver and thyroid. in: Sherlock S, ed. Diseases of the Liver and Biliary System. 8th. ed. Oxford, UK: Blackwell Scientific Publication. 1989: 495-496.

12) Fong TL, McHutchison JG, Reynolds TB. Hyperthyroidism and hepatic dysfunction. A case series analysis. J Clin Gastroenterol 14: 240244, 1992.

13) Huang MJ, Li KL, Wei JS, Wu SS, Fan KD, Liaw YF. Sequential liver and bone biochemical changes in hyperthyroidism: prospective controlled follow-up study. Am J Gastroenterol 89: 1071-1076, 1994.

14) Smith AC, Roberts SM, Berman LM, Harbison RD, James RC. Effects of piperonyl butoxide on halothane hepatotoxicity and metabolism in the hyperthyroid rat. Toxicology 50: 95-105, 1988.

15) Videla LA, Smok G, Troncoso P, Simon KA, Junqueira VB, Fernandez $\mathrm{V}$. Influence of hyperthyroidism on lindane-induced hepatotoxicity in the rat. Biochem Pharmacol 50: 1557-1565, 1995.

16) Hartleb M. Do thyroid hormones promote hepatotoxicity to acetaminophen? Am J Gastroenterol 89: 1269-1270, 1994 (letter).

17) Kumashiro R, Hino $T$, Koga $Y$, et al. A diet pills-induced acute hepatitis. Acta Hepatol Jpn 44: 113-116, 2003 (Japanese).

18) Koga $\mathrm{H}$, Taguchi J, Ishii $\mathrm{K}$, et al. A survival case of fluminant hepatic failure caused by Chinese diet medicine (Sennomotokounou). Acta Hepatol Jpn 44: 117-122, 2003 (Japanese).

19) Mochida S. Acute hepatitis induced by Chinese dietary supplements for weight loss. Acta Hepatol Jpn 44: 89-91, 2003 (Japanese). 